THE IMPORTANCE OF BUILDING CULTURAL BRIDGES BETWEEN EUROPE AND EGYPT. THE ROLL OF TOURISM

\author{
By \\ Morejón, José Alipio. PhD
}

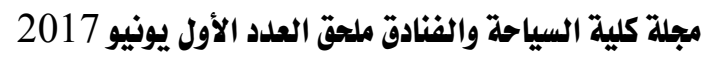

الخاص بالمؤتتر العلمي الأول السياحة و الاثار - الفرص و التحديات 


\section{THE IMPORTANCE OF BUILDING CULTURAL BRIDGES BETWEEN EUROPE AND EGYPT. THE ROLL OF TOURISM \\ Morejón, José Alipio. PhD}

\section{Abstract.}

Building cultural bridges between Europe and Egypt is necessary.

Egypt is a country with an exceptional cultural importance in the world, and very specifically in Europe. Without the contribution of Egypt, Europe would be different, and certainly less culturally rich. enrichment.

Tourism is a magnificent instrument of cultural and human

Cultural examples that the author have personally verified through his rich experience in numerous cultural tours and activities, which work very well in Europe and other countries of the world, and that according to Egyptian history and cultural heritage and the vital interests of Europeans could work well in Egypt, and contribute to its development.

\section{Conference}

It is a real and great honour to be here at this international Conference organized by the University of Al Mansoura.

I would like to warmly thank the President of the University, the authorities of the Faculty of Tourism and the organizers of the Conference for the invitation to participate in this important and so well organized international event. Congratulations.

Because of my experience through the institution I have the honour to work on, Roots of Europe, whose goal is to promote the integration and unity of the different countries and regions of Europe through culture, organizing hundreds of courses, conferences, talks and academic trips, I know that building bridges between different cultures and civilizations, has always been and will be a fundamental necessity for the development of humanity.

And today, with so many difficulties in the world, I think that this effort of union and collaboration is more necessary than ever.

I am sure that if we strive to know each other in a better way, to understand more about the people from different cultures, to search for everything that unites and enriches us, to collaborate between different continents, countries and people, humanity will become better and happier, a fundamental goal for all of us. 
We must seek common ground, join forces to face such great challenges as peace, justice, family, friendship, education, freedom, solidarity, quality of employment and housing, health, order, spirituality and transcendence. In few words: happiness of the people.

I would like to speak very concretely about the necessity to build bridges between my continent, Europe, which I love so much -now, when I was in Munich airport to take the plane to Cairo, I realise how well this country works-, between Europe and Egypt, this amazing country, with such exceptional history, human and cultural wealth.

Speaking and encouraging a better relationship and collaboration between Europe and Egypt is a worthy and exciting task, which will lead to beautiful fruits of coexistence, human and cultural enrichment, well-being and happiness.

I am sure that Europe needs Egypt, not only because of its rich history and culture, but also, for example, to learn so much about the strong sense of family, hospitality and friendship you have, the joy of life I see in young people, so numerous here, as well as the sense of transcendence, so important for the present and future of every society.

Just because of the invitation to this international conference I am thinking a about this topic and areas of union and collaboration, especially through tourism, a so important activity and job.

A very significant one is the cultural area. A society without culture is like a body without soul. And culture and tourism are firmly linked, and Egypt is one of the most culturally rich countries in the world.

Egypt offered an outstanding contribution to the culture of the world, and very concretely to Europe. My continent would be so different, and certainly less culturally rich without Egypt.

The great civilization of the pharaohs had a great influence in the European culture, that through Greece allowed important cultural manifestations to Europe, in its architecture, sculpture, painting, as well as many other notable aspects of medicine, geometry, music, law, religion and many others.

Without Egypt, probably we would not have wonders like the Parthenon of Athens and the great Greek sculpture and painting of Myron, Phidias or Apelles.

And with the arrival of Alexander the Great and the Ptolemaist, Egypt renewed its contribution to the Greek and Mediterranean world, which will give rise to that mature fruit of the Hellenistic art. 
For this and many other reasons, we must promote more and more the knowledge of the amazing cultural heritage of Ancient Egypt, and to make it easier to know, not only to admire, but to understand the background of these monuments.

And important goal for it is to have very good guides, with a rich cultural and human formation, along with experts who help making this impressive knowledge accessible to millions of tourists who should come to your country every year. For this you need very good faculties in tourism, with very good professors and students.

As Egypt's wealth of heritage is so great, it would be normal for European citizens to come to this country several times in their lives, not to only admire the most famous monuments, like the pyramids of Giza or the temples of Karnack or Luxor.

Besides these and other magnificent monuments, it is necessary to facilitate the knowledge of many other valuable archaeological sites you have, less known, and mostly unknown to the majority of the Europeans, but so beautiful and worthy.

It would be also necessary to promote and make better knowing to the new archaeological findings, with the collaboration of archaeologists of European centres and universities, which could be formed here, and fall in love with the Egyptian country, and later on become ambassadors of its culture.

Next to the ancient Egypt of the Pharaohs, there is the muslin Egypt.

Since the coming of the Islam in the 7th century, Egypt has also been an important Islamic centre, which lived moments of splendour under Saladin or the Mamluks, when magnificent mosques were erected.

Egypt was also a precious example of coexistence between Muslims and Christians, which, except for some isolated and sad experience, still lasts.

Although the great sacred sites of Islam are mainly the Mecca, Medina and Jerusalem, it is undoubtedly that if you facilitate more and more the visit of European tourists in so many ancient and beautiful mosques, like those of Al-Azhar, Al-Hakim, Ibn Tulun, Sayeda Zainab and so many other, it will be an ever-increasing attraction for Europeans, who would also find in them a beautiful occasion of prayer to God, Merciful and all Justice, and would make it easier for more people to come to Egypt.

But in addition to the impressive world of the pharaohs and the Islamic Egypt, this country is a fundamental land for the people who have 
built their civilization from the Bible, as it is Europe, which cannot be understood without its very strong Christian roots.

Actually, the Bible cannot be understood without Egypt, because in Egypt lived many of the most outstanding people of the biblical world, such as: Canaan.

Abraham and Sarah, who here find refuge during the hunger in

Jacob, son of Isaac, son of Abraham and Sarah, who lived in Egypt one of the happiest moments of his life, the meeting with Joseph, his loved son, and where he passed his last years.

The aforementioned Joseph, whose life in Egypt is one of the most beautiful examples of the Bible.

In Egypt also lived the 12 sons of Jacob: from Judah to Joseph and Benjamin. And here they grew up and became a great people. Moses.

One of the greatest biblical characters was born and lived in Egypt:

In Egypt, the Jewish Passover took place, which is so important to understand the Christian Passover.

The great covenant with God was sealed at Sinai, where he gave the Ten Commandments and where so many other transcendental facts took place.

In Egypt, especially in Alexandria, a very important Jewish community grew, and here were made the most important translation of the Bible into Greek.

In Egypt found refuge Mary the Virginal Mother of Jesus, Joseph and Jesus, Isa, Jesus Christ, Lord and Saviour for Christians, and one of the greatest prophets for Muslims.

In Egypt, with the preaching of the evangelist Mark two thousand years ago in Alexandria and other parts of the country, Christianity developed from the very beginning with an extraordinary strength.

The great saints of Egypt had a huge influence on the development of Christianity in Europe, contributing to the Christian European way of thinking and believing in the one God. Numerous figures could be mentioned, like Saint Athanasius, the great patriarch of Alexandria, decisive for the configuration of Christian theology; Saint Antonio Abad, born in Heracleopolis Magna (near the site of Neny-nesut), so important for the conversion to the Christian faith of one of the most influence saints of Europe: St. Augustine; and Saint Pachomius, decisive along with the 
aforementioned Antonio, in the foundation and development of monasticism, without which it is not possible to understand Europe.

The reality and importance of the referred facts connects Europe with Egypt in a unique way. It is so important for Europe and our cultural roots. There is no doubt that all the places referred to the people and facts before mentioned, if their knowledge and visit were better facilitated, will become an important new reason for many Europeans to come to Egypt. Actually, we cannot forget that the religious cultural tourism moves more than three hundred million visitors every year, many of them Europeans, who could look to Egypt as one of its main goals.

In Europe we have extraordinary examples of religious cultural tourism such as Rome, visited every year for more than twenty million people looking for the tomb of the apostle St. Peter, and others apostles.

The same it is in the great shrines linked to the Virgin Mary, such as that of Fatima in Portugal or Lourdes in France, visited every year by more than 5 million people, who usually spend several days in these places of faith and culture .

The same happens with the great monasteries of Europe, like Monte Cassino in Italy, Einsiedeln in Switzerland, Tyniec in Poland, Silos or Montserrat in Spain, and many other, that every year welcomed millions of visitors, spending generally several days in them.

We also have experiences of pilgrimage that are even longer in time, such as the Camino (Way) of Santiago in Spain, a religious and cultural itinerary which was born in the 9th century, when thousands of pilgrims from all over Europe try to reach the tomb of the Apostle James, on the western borders of Europe.

This Road has been reborn with great force in the last years, and now more than two hundred thousand people travel every year through it for several weeks, mostly by walking during a month or more, in addition to millions of tourists who go to Santiago by car, train or plane. This religious and cultural tourism experience allows you to fully understand the rich cultural heritage of this itinerary in the North of Spain, while meeting with people from all over the world, exchanging knowledge, facilitating new friendships, and leaving many benefits in all the places they visit.

The same kind of experience is growing in Spain around other great religious figures, such as Ignatius of Loyola, founder of the Jesuits, or Therese of Jesus, great religious reformer, facilitating itineraries to remember there amazing lives. 


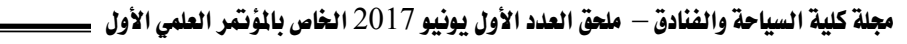

These experiences, which usually lasts several weeks, is developing in many other places in Europe, such as the Way of Francis of Assisi, whose goal is the tomb of the Saint in central Italy, the Via Francigena (the common name of an ancient road and pilgrim route running from France to Rome), which revives the way of the pilgrims who went to Rome hundreds of years ago from all over Europe, passing through many towns and cities of Italy before arriving to the tombs of the apostles Peter and Paul.

These experiences are so satisfying, that many of those who make it repeat many times in life.

The visitors of these places and itineraries are a very good example of tourism of quality, which is an important goal for this world of tourism, which also means for the countries and places that offer these itineraries and strong spiritual and material enrichment.

I think it could be promoted in Egypt, especially around the extraordinary routes made by Moses during the Exodus, from Egypt to the land of Canaan through the Red Sea and the Sinai, or the one made by Mary, Joseph and Jesus, from Bethlehem to Egypt, as well as his return to Nazareth in Galilee from Egypt.

And also the visit of the great monasteries of Egypt, of the many who still survive, some with more than fifteen hundred years of life, sometimes linked to saints so loved in Europe as San Antonio Abad, Saint Paul or San Pacomio, parents of monasticism, and many others like the monastery of San Antonio next to the Red Sea, the monastery of St. Paul, the friend and disciple of St. Anthony, Santa Catalina monastery in Sinai, the White Convent, from the middle of the fifth century, Deir el-Ahmar, the Red Convent, located a few kilometres from the previous one; the Coptic monasteries, just over 100 kilometres from Cairo, the monasteries of San Bishoi and Suriani, and many other, many of them among the most ancients of the world.

These experiences would be enormously gratifying for hundreds of thousands of Europeans, who, if they are better prepared, would be encouraged to repeat the experience many times, and to encourage doing the same to their friends.

I know that many things are already be done, but if you think about how to improve it, work on it, and improve the marketing and the structures of these itineraries, it would certainly be a very good way to increase the number and quality of visitors to Egypt, who would able to combine these 
specific places with the most well known of the ancient Egypt of the pharaohs...

Our experience in these areas during more than twelve years of activity in Roots of Europe, with more than 120 different trips all over Europe and the world, and well conscious of the increasingly interest of many European people with these trips, moves me to encourage you, experts of tourism, in this direction.

I would also like that many citizens from Egypt could come to my country, Spain, and were able to know our rich heritage, also with strong Islamic influences, as in the Alhambra of Granada, The Cathedral of Seville, and the Mosque of Cordoba, in addition to knowing their most beautiful and genuine monuments, and Its people and rich culture.

I hope that these ideas about places to visit, and ways to do it, along with so many other wonders you can admire in your country, also natural places like the Nile, the Red Sea, the Mediterranean or the desert, as well as your cities, its markets, and, especially, it's amazing friendship and hospitality, should help to make of Egypt one of the main goals of European tourists, and contribute to make your country an extraordinary cultural, economic and human power in the world, which will promote effectively the peace, justice, freedom, prosperity and many other great values, which fruits will be the happiness among its citizens and many other in the world. 